EISSN: 2706-7955 ISSN: 2077-4605

DOI: 10.36632/mejar/2021.10.1.27

Journal homepage: www.curresweb.com

Pages: 413-425

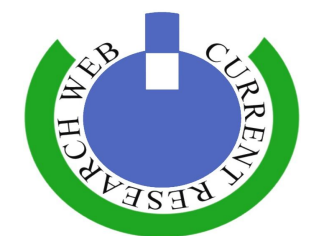

\title{
Productivity and Phytochemical Composition of caraway (Carum carvi L.) plant in Response to Alternaria alternata as One of Endophytic Fungi and Nitrogen Fertilization grown under newly Reclaimed Sandy Soil Conditions
}

Nagwa R.A. Hussein ${ }^{1}$, Atef A.S. Abdel-Kader ${ }^{2}$ and Yassmin M. Shebany ${ }^{1}$

${ }^{1}$ Botany and Microbiology Dept., Fac. Sci., South Valley Univ., Qena, Egypt

${ }^{2}$ Medicinal and Aromatic plants Dept., Hort. Res. Inst., A.R.C., Egypt

Received: 20 January $2021 \quad$ Accepted: 25 March $2021 \quad$ Published: 30 March 2021

\begin{abstract}
The present work was conducted during 2018/2019 and 2019/2020 seasons in newly reclaimed soil at Al-Marashda Agricultural Research Station, Qena, Egypt to study the productivity and phytochemical composition of caraway (Carum carvi L.) plant as response to spraying Alternaria alternata as endophytic fungus at $0.3 \%$ three times $(0,3$ and 6 times per season) and three nitrogen levels $(0,30$ and $60 \mathrm{~kg} \mathrm{~N} /$ feddan) as ammonium sulfate and their combinations. Obtained data indicated that the vegetative growth and fruit characteristics, essential oil percentage and oil yield/feddan as well as leaf contents of N, P, K and total soluble carbohydrates of caraway plant significantly affected by spraying endophytic fungus and $\mathrm{N}$ fertilizer treatments. The most effective for the growth characteristics and productivity was due to spraying 6 times per season of endophytic fungus and using $60 \mathrm{~kg} \mathrm{~N} / \mathrm{fed}$. Compared to the other treatments. Meanwhile, the highest values of total carbohydrates, essential oil percentage and oil yield/fed. were obtained when plants were sprayed 3 times by endophytic fungus and fertilized with $60 \mathrm{~kg} \mathrm{~N} / \mathrm{fed}$. in the two seasons. Mostly, high P and $\mathrm{K}$ contents in leaves were resulted from plants sprayed with endophytic fungus at 6 times per season combined with $30 \mathrm{~kg} \mathrm{~N} / \mathrm{fed}$. Compared to the other treatments. Phytochemical composition of the essential oil in caraway fruits using GLC analysis indicated that, the most important compounds are carvone (major compound), limonene, linalool, caryophyllene, $\beta$-pinene, $p$-cymene, $\alpha$-pinene, carveol and dihydrocarvone. Most of the different treatments of endophytic fungus and nitrogen fertilizer improvement content most of these components and markedly increased quality of essential oil (oil \%, carvone content and carvone to limonene ratio) compared to the control (untreated plants). Therefore, it can be concluded that using $A$. alternta as endophytic fungus with $60 \mathrm{~kg} \mathrm{~N} / \mathrm{fed}$. as ammonium sulphate can improve the growth, productivity and quality of caraway plants under the reclaimed sandy soil conditions without the need for excessive chemical fertilization to obtain safe and healthy production for the various purposes of these important plants.
\end{abstract}

Keywords: Carum carvi, endophytic fungi, ammonium sulfate, essential oil, chemical composition.

\section{Introduction}

In Egypt, there is a tendency to increase the agricultural lands according to the political orientations by increasing the expansion of newly reclaimed soils. Also, due to the scarcity of water and the need to preserve it, there is a tendency to use modern irrigation systems to save the amounts of irrigation that are consumed by the flood irrigation system. Also, an excess of soluble salts in sandy soil leads to a reduction in the plant growth, yield and oil content for some medicinal plants (Ashraf and Orooj, 2006). Many researchers confirmed the effect of newly reclaimed soil on the chemical composition of essential oils for different medicinal plants (Shalan et al., 2006; Matter and El Sayed, 2015).

Carum carvi L. belongs to the family Apiaceae, one of the earliest cultivated herbs in different countries. It is commonly known as caraway, which is grown for its high content of essential oil in their seeds. The essential oil of caraway is obtained by the steam distillation of the dried fruits. The major

Corresponding Author: Nagwa R.A. Hussein, Botany and Microbiology Dept., Fac. Sci., South Valley Univ., Qena, Egypt 
compounds in caraway are carvone, $\alpha$-pinene, limonene, $\gamma$-terpinene, linalool, carvacrol and p-cymene (Kocourkova et al., 1999). Caraway can be introduced into livestock feed, as it increases the excitability of the diet, facilitates digestion, and increases milk production. Caraway fruits have medicinal effects, including stimulating, expectorant and anti-spasmodic effects. They are also used to treat stomach pain, constipation and nausea, and they increase the secretion of gastric juice and bile, which increases appetite and leads to stimulation of the digestive system (Dyduchet al., 2006; Peter, 2006; Sembratowicz and Czech, 2005).

Endophytic fungi involved in phytoremediation process have shown tremendous potential in improving phytoremediation processes as reducing availability of metals, altering soil $\mathrm{pH}$, releasing chelating agents and improving enzymatic properties (Khan et al., 2009; Wenzel, 2009; Urozet al., 2009). However, the plant-associated microorganisms play essential roles for agriculture and food safety as well as contribute to maintain environmental equilibrium. These beneficial fungi can improve the growth and nutrient uptake of the plants, fix nitrogen, decrease plant stress and disease incidence that influence on the plant development and yield. Some of them can also be useful for protection against numerous pathogens (Montesinos, 2003). Also, Shebany and Abdel-Kader (2013) concluded that endophytic fungi application especially, Alternaria alternata was more effective for growth characteristics and oil \%, yield and composition as well as N, P, K and Ca contents in dry leaves of sweet basil plants than non- inoculated plants, which may indicate effective symbiotic potential of this species with basil plants.

The influence of nitrogen fertilization on the growth and essential oil content in caraway plant was studied by different researches (El-Din et al., 2010; Kozera et al., 2013; Aüimoviü et al., 2015). Also, Baranauskienn et al., (2003) revealed that nitrogen application resulted in an increase of total oil yield of Thymus vulgaris. Meanwhile, Swarupa et al., (2003) revealed that the maximum growth parameters and seed yield of Plantago ovata plants were obtained when plants treated with $50 \mathrm{~kg} \mathrm{~N}$ ha ${ }^{-1}$ and $30 \mathrm{~kg} \mathrm{P}_{2} \mathrm{O}_{5} \mathrm{ha}^{-1}$. On the other hand, Paschalina et al., (2006) pointed out that essential oil yield and composition of fennel cultivars did not affected by nitrogen levels $\left(60,80,100 \mathrm{~kg} \mathrm{ha}^{-1}\right)$. Moreover, Omer et al., (2008) pointed out that application of ammonium sulfate at a rate of $60 \mathrm{~kg} \mathrm{fed}^{-1}$ at two equal doses is recommended to produce the maximum volatile oil yield in Ocimum americanum. Meanwhile, Kandil et al., (2009) revealed that application of compost (organic fertilizer) affects the composition of essential oil of $O$. basilicum in the same way as the effect of ammonium nitrate as an inorganic fertilization. Adding compost to basil plants not only increases oil yield, but also increases content of linalool in the oil, and at the same time decreases methyl chavicol and 1, 8-cineole content (Taie et al., 2010). Also, Abdel-Rahman et al., (2008) on fennel plant revealed that application of active dry yeast at $4 \mathrm{~g} / \mathrm{l}$ as biofertilizer with $100 \mathrm{ppm}$ tryptophan as organic nitrogenous source gave nearly equal results to those obtained with the high level of mineral nitrogen fertilizer ( $100 \mathrm{~kg} \mathrm{~N} / \mathrm{fed}$.) alone. The maximum vegetative and flowering growth, fruit and oil yield as well as leaf nutrients content were obtained from the combined treatment of $50 \mathrm{~kg} \mathrm{~N} /$ fed. +2 or $4 \mathrm{~g} / \mathrm{l}$ active dry yeast $+50 \mathrm{ppm}$ tryptophan.

Therefore, the aim of this study was to investigate the influence of endophytic fungus (Alternaria alternate) and nitrogen fertilizer as ammonium sulfate on the growth, fruit yield, essential oil percentage, oil yield and its components of caraway plants grown under newly reclaimed soil conditions.

\section{Materials and Methods}

\subsection{Site, experimental description and planting seeds}

This study was carried out under drip irrigation during the two successive seasons of 2018/2019 and 2019/2020 at Al-Marashda Agricultural Research Station, Agric. Res. Center (ARC), Qena Governorate, Egypt (which, lies between latitude $26^{\circ}, 09^{\prime} \mathrm{N}$, longitude $32^{\circ}, 42^{\prime} \mathrm{E}$ ). The main objective was to study the influence of endophytic fungus i.e. Alternaria alternata and nitrogen fertilizer as ammonium sulfate $(20.5 \% \mathrm{~N})$ on the growth and production of caraway (Carum carvi L.) plants grown under newly reclaimed sandy soil conditions. The fruits of caraway (Carum carvi L.) were obtained from the Medicinal and Aromatic Dept., ARC, Ministry of Agriculture, Egypt and sown in newly reclaimed sandy soil at the beginning of November for both seasons. Soil samples were obtained from a depth of $30 \mathrm{~cm}$ from the used soil surface in this study and some physical and chemical properties of the soil were done according to the methods described by Jackson (1973) and Black et al., (1982) as 
shown in Table (1). The organic fertilization as commercial compost at rate of 5 tons/fed. was applied and incorporated to the top $5 \mathrm{~cm}$ layer of the experiment soil before the sowing seeds in each season in only one dose. The chemical characteristics of the used compost are shown in Table (2).

A spilt-plot in randomized complete block design (RCBD) with three replicates was followed in this experiment. The experiment contained of 9 treatments. The three levels of nitrogen fertilizer (control, 30 and $60 \mathrm{~kg} \mathrm{~N} /$ fed.) were presented in the main-plots, while spraying times of endophytic fungus (Alternaria alternate) i.e. control, 3 and 6 times per season were assigned in sub-plots. Each sub-plot of $3.0 \times 3.5 \mathrm{~m}$ contained 7 rows. The planting distance was $25 \mathrm{~cm}$ between plants and each row contained 12 hills. After 45 days from planting, the plants were thinned to one plant per hill (84 plants/sub plot) i.e. 33,600 plants/fed.

Nitrogen fertilizer in the form of ammonium sulfate $(20.5 \%)$ was applied with irrigation water in six equal doses after 45 days from seed sowing until the beginning of flowering. Meanwhile, endophytic fungus (Alternaria alternate) was sprayed three times per season. The first time of spraying began after 45 days from sowing seeds and the rest times was applied at 15 days intervals. Stock culture of Alternaria alternata fungus $\left(4 \times 10^{2} \mathrm{cfu} \mathrm{ml}^{-1}\right)$ was diluted with tap water to produce a $0.3 \%$ solution and the prepared solution was used immediately. Watering was applied as drip irrigation according to the need of the caraway plants and the soil condition, water analysis is shown in Table (3). All other agricultural practices were carried out as recommended.

Table 1: Some of the physical and chemical properties of the experimental soil site during 2018/2019 season.

\begin{tabular}{|c|c|c|c|c|c|c|c|}
\hline \multirow{2}{*}{$\begin{array}{r}\text { Texture } \\
\text { class }\end{array}$} & \multicolumn{3}{|c|}{ Particle size distribution } & \multirow{2}{*}{\multicolumn{2}{|c|}{$\mathrm{CaCO}_{3} \%$}} & \multirow{2}{*}{$\begin{array}{c}\mathrm{EC}\left(\mathrm{dS} \mathrm{m}^{-1}\right) \\
(1: 2.5)\end{array}$} & \multirow{2}{*}{$\begin{array}{r}\mathbf{p H} \\
(1-5) \\
\end{array}$} \\
\hline & Sand $\%$ & Silt \% & Clay \% & & & & \\
\hline Sandy & 81.3 & 12.7 & 6.0 & & & 3.01 & 8.08 \\
\hline \multicolumn{4}{|c|}{ Cation ( meq $\left.L^{-1}\right)$} & \multicolumn{4}{|c|}{ Anion $\left(\right.$ meq $\left.L^{-1}\right)$} \\
\hline $\mathbf{N a}^{+}$ & $\mathbf{K}^{+}$ & $\mathbf{C a}^{++}$ & $\mathbf{M g}^{++}$ & $\mathrm{CO}_{3}^{--}$ & $\mathrm{HCO}_{3}{ }^{-}$ & $\mathrm{Cl}^{-}$ & $\mathrm{SO}_{4}^{--}$ \\
\hline 30.02 & 0.88 & 12.0 & 6.2 & 0.0 & 0.82 & 30.6 & 17.9 \\
\hline
\end{tabular}

Table 2: Chemical analysis of the commercial compost used in the experimental site.

\begin{tabular}{|c|c|c|c|c|c|c|c|c|c|c|}
\hline Character & $\begin{array}{c}\text { pH } \\
(1: 5)\end{array}$ & $\begin{array}{c}\text { EC } \\
\left(\mathrm{dS} \mathrm{m}^{-1}\right) \\
(1: 2.5)\end{array}$ & O.M\% & N\% & P\% & $\mathrm{K} \%$ & $\begin{array}{r}\mathrm{C} / \mathrm{N} \\
\text { ratio }\end{array}$ & $\begin{array}{c}\text { Moisture } \\
\text { content } \\
\%\end{array}$ & $\begin{array}{c}\text { O.C } \\
\%\end{array}$ & Са \% \\
\hline Value & 7.9 & 4.7 & 47.4 & 1.4 & 1.2 & 1.6 & $1: 16$ & 29.7 & 21.2 & 5.8 \\
\hline
\end{tabular}

Table 3: Water analysis of the irrigation water used for the experimental site.

\begin{tabular}{|c|c|c|c|c|c|c|c|c|c|c|}
\hline \multirow{2}{*}{$\begin{array}{l}\text { TDS } \\
\mathrm{mg} / \mathrm{l}\end{array}$} & \multirow{2}{*}{$\begin{array}{c}\mathrm{pH} \\
(1: 5)\end{array}$} & \multirow{2}{*}{$\begin{array}{c}E C \\
\left(\mathrm{dS} \mathrm{m}^{-1}\right) \\
(\mathbf{1}: \mathbf{2 . 5})\end{array}$} & \multicolumn{4}{|c|}{ Soluble cations (mg/l.) } & \multicolumn{4}{|c|}{ Soluble anions (mg/l.) } \\
\hline & & & $\mathbf{C a}^{++}$ & $\mathbf{M g}^{++}$ & $\mathbf{N a}^{+}$ & $\mathbf{K}^{+}$ & $\mathrm{CO}_{3}^{--}$ & $\mathrm{HCO}_{3}$ & $\mathrm{SO}_{4}^{--}$ & $\mathrm{Cl}^{-}$ \\
\hline 225.5 & 7.3 & 3.25 & 28.5 & 8.8 & 31.6 & 6.2 & 24.7 & 110.5 & 41.6 & 31.2 \\
\hline
\end{tabular}

\subsection{Fungal isolation, identification and cultivation}

The leaves of Inga edulis trees were collected from a private farm in Qena Governorate, Egypt. Leaf samples were washed carefully with tap water, then with sterile distilled water. The surface of the samples was sterilized by sequential immersion in $75 \%$ ethyl alcohol for 1 minute, $4 \%$ sodium hypochlorite for 3 minutes and finally $75 \%$ ethyl alcohol for 30 seconds. Samples were then rinsed using sterile distilled water, and shade-drying (Filip et al., 2003). The leaves were then cut into small pieces and placed on pre-poured glucose-Czapek's agar plates according to Smith and Dawson (1944) and then incubated at $28 \pm 2^{\circ} \mathrm{C}$ for $2-3$ weeks in a microbiological incubator until the desired fungus growth i.e. Alternaria alternata.

\subsection{Growth and yield characteristics}

At full ripeness fruit stage in the first of May caraway plants were harvested. Ten plants were randomly chosen from each experimental unit in both seasons and submitted to measure the following plant growth parameters and yield; plant height $(\mathrm{cm})$, branch number/plant, plant fresh and dry weight (g), umbel number/plant, weight of 1000 fruits $(\mathrm{g})$, fruit yield per plant $(\mathrm{g})$ and fruit yield per feddan 
(kg). However, total fruit yield/feddan was estimated by multiplying fruit yield/plot by 400 (plot number per feddan).

\subsection{Chemical constituents}

The chemical constituents in dry leaves of caraway plants were determined at the end of experiments. Nitrogen, phosphorus and potassium percentages were determined according to the method described by Cottenie et al., (1982). Total carbohydrates percentage was determined calorimetrically according to Herbert et al., (1971). The essential oil percentage in caraway fruits was extracted by hydro-distillation according to Guenther (1961). Oil yield/feddan was calculated by multiplying the essential oil percentage by fruit yield/feddan. However, GLC analysis of volatile oil was used for the different treatments using Hewlett-Packard GC. model 5890. Carbowax was a combined $20 \mathrm{~m}$ silica capillary column measuring $20 \mathrm{~m}$ x $0.32 \mathrm{~mm}$ with an inner diameter, a film thickness of $0.17 \mu \mathrm{m}$, the temperature was $75^{\circ} \mathrm{C}$ for 5 minutes and increased $4^{\circ} \mathrm{C} / \mathrm{min}$ to $220^{\circ} \mathrm{C}(10$ minutes). Helium is the carrier gas and the working flow rate is $1.0 \mathrm{ml} / \mathrm{min}$, and the detector was 9144 $\mathrm{hp}$. The temperature of the detector is $280^{\circ} \mathrm{C}$ and the injector is $240^{\circ} \mathrm{C}$. The separated compounds were determined by matching their retention times with those of the original samples that were injected under the same conditions.

\subsection{Statistical analysis}

The obtained data were subjected to the statistical analysis of variance by using Statistix 8.1 software (Analytical Software, 2005). The means were compared using the least significant difference (L.S.D.) test at probability level of $\leq 0.05$ for comparison according to Gomez and Gomez (1983).

\section{Results and Discussion}

\subsection{Growth characteristics}

The growth characteristics of caraway plants as affected by endophytic fungus (Alternaria alternate) and nitrogen fertilizer are shown in Tables (4, 5, 6 and 7$)$ during the two studied seasons. The tabulated data revealed that there are significant differences in the plant height, branch number, fresh and dry weight of caraway plants as a result of endophytic fungus and nitrogen fertilizer treatments during the two seasons. However, the highest values of these parameters were obtained when plants sprayed with A. alternate 6 times per season compared to control and the other spraying times. Meanwhile, nitrogen fertilizer at a rate of $60 \mathrm{~kg} \mathrm{~N} /$ feddan was more effective and significantly increased vegetative growth characteristics as compared to the control in both seasons. On the other hand, the interaction effect between endophytic fungus and nitrogen fertilizer treatments was not significant for plant height and branch number in the two seasons, while it was significant for plant fresh and dry weight in both seasons. These results are in accordance with those obtained by Nofal et al., (2001), ElTohamy and El-Greadly (2007), Kenawy (2010), Matter and El Sayed (2015) and Ahmed (2017). Meanwhile, Ebeid and Shebany (2017) pointed out that treatment of Chrysophyllum oliviforme plants with endophytic fungi (A. alternata) improved the seedling growth characteristics and leaf mineral content.

Table 4: Plant height $(\mathrm{cm})$ of caraway plants as affected by endophytic fungus (Alternaria alternata) and nitrogen fertilizer during 2018/2019 and 2019/2020 seasons.

\begin{tabular}{|c|c|c|c|c|c|c|c|c|}
\hline \multirow{4}{*}{$\begin{array}{c}\text { Nitrogen Fertilizer } \\
\text { (A) }\end{array}$} & \multicolumn{7}{|c|}{ Plant height (cm) } & \\
\hline & \multicolumn{4}{|c|}{$2018 / 2019$} & \multicolumn{4}{|c|}{$2019 / 2020$} \\
\hline & \multicolumn{8}{|c|}{ Spraying times of endophytic fungus $(B)$} \\
\hline & Control & 3 times & 6 times & Mean & Control & 3 times & 6 times & Mean \\
\hline Control & 83.3 & 83.5 & 88.5 & 85.1 & 75.4 & 80.3 & 84.8 & 80.2 \\
\hline $30 \mathrm{~kg} \mathrm{~N} /$ feddan & 83.2 & 89.2 & 93.7 & 88.7 & 78.7 & 83.1 & 87.8 & 83.2 \\
\hline $60 \mathrm{~kg} \mathrm{~N} /$ feddan & 92.3 & 95.0 & 105.5 & 97.5 & 90.5 & 95.6 & 101.1 & 95.7 \\
\hline Mean & 86.3 & 89.2 & 95.9 & & 81.5 & 86.3 & 91.2 & \\
\hline \multirow{2}{*}{ LSD at 0.05} & $\mathrm{~A}$ & $\mathrm{~B}$ & $\mathrm{AB}$ & & $\mathrm{A}$ & $\mathrm{B}$ & $\mathrm{AB}$ & \\
\hline & 3.5 & 2.6 & N.S & & 1.5 & 1.50 & N.S & \\
\hline
\end{tabular}


Table 5: Branch number/plant of caraway plants as affected by endophytic fungus (Alternaria alternata) and nitrogen fertilizer during 2018/2019 and 2019/2020 seasons.

\begin{tabular}{|c|c|c|c|c|c|c|c|c|}
\hline \multicolumn{9}{|c|}{ Branch number / plant } \\
\hline \multirow{3}{*}{$\begin{array}{l}\text { Nitrogen } \\
\text { Fertilizer } \\
\text { (A) }\end{array}$} & & 2018/2 & & & & 201 & 2020 & \\
\hline & \multicolumn{8}{|c|}{$\begin{array}{l}\text { Spraying times of endophytic fungus }(B) \\
\end{array}$} \\
\hline & Control & 3 times & 6 times & Mean & Control & 3 times & 6 times & Mean \\
\hline Control & 8.0 & 9.8 & 11.3 & 9.7 & 7.1 & 9.0 & 10.9 & 9.0 \\
\hline $30 \mathrm{~kg} \mathrm{~N} /$ feddan & 9.2 & 10.7 & 12.1 & 10.7 & 8.3 & 10.2 & 11.6 & 10.0 \\
\hline $60 \mathrm{~kg} \mathrm{~N} /$ feddan & 10.2 & 12.0 & 12.9 & 11.7 & 9.6 & 11.9 & 14.0 & 11.8 \\
\hline Mean & 9.1 & 10.9 & 12.1 & & 8.3 & 10.4 & 12.1 & \\
\hline \multirow{2}{*}{ LSD at 0.05} & A & B & $\mathrm{AB}$ & & A & $\mathrm{B}$ & $\mathrm{AB}$ & \\
\hline & 0.6 & 0.5 & N.S & & 0.5 & 0.38 & N.S & \\
\hline
\end{tabular}

Table 6: Fresh weight (g/plant) of caraway plants as affected by endophytic fungus (Alternaria alternata) and nitrogen fertilizer during 2018/2019 and 2019/2020 seasons.

\begin{tabular}{|c|c|c|c|c|c|c|c|c|}
\hline \multirow{4}{*}{$\begin{array}{l}\text { Nitrogen Fertilizer } \\
\text { (A) }\end{array}$} & \multicolumn{7}{|c|}{ Fresh weight ( g/plant ) } & \\
\hline & \multicolumn{4}{|c|}{ 2018/2019 } & \multicolumn{4}{|c|}{$2019 / 2020$} \\
\hline & \multicolumn{8}{|c|}{ Spraying times of endophytic fungus (B) } \\
\hline & Control & $\begin{array}{c}3 \\
\text { times }\end{array}$ & $\begin{array}{c}6 \\
\text { times }\end{array}$ & Mean & Control & $\begin{array}{c}3 \\
\text { times } \\
\end{array}$ & $\begin{array}{c}6 \\
\text { times }\end{array}$ & Mean \\
\hline Control & 223.3 & 236.0 & 246.8 & 235.4 & 228.5 & 237.4 & 245.0 & 237.0 \\
\hline $30 \mathrm{~kg} \mathrm{~N} /$ feddan & 244.9 & 256.5 & 264.3 & 255.6 & 247.0 & 257.1 & 266.6 & 256.9 \\
\hline $60 \mathrm{~kg} \mathrm{~N} /$ feddan & 253.3 & 273.1 & 294.1 & 273.5 & 264.2 & 277.7 & 293.9 & 278.6 \\
\hline Mean & 240.5 & 255.5 & 268.4 & & 246.6 & 257.4 & 268.5 & \\
\hline I CD 005 & A & $\mathrm{B}$ & $\mathrm{AB}$ & & A & $\mathrm{B}$ & $\mathrm{AB}$ & \\
\hline LSD at 0.05 & 1.4 & 2.0 & 3.5 & & 3.1 & 2.0 & 3.5 & \\
\hline
\end{tabular}

Table 7: Dry weight (g/plant) of caraway plants as affected by endophytic fungus (Alternaria alternata) and nitrogen fertilizer during 2018/2019 and 2019/2020 seasons.

\begin{tabular}{lcccccccc}
\hline & \multicolumn{7}{c}{ Dry weight ( g/plant ) } \\
\hline Nitrogen & \multicolumn{7}{c}{$\mathbf{2 0 1 8 / 2 0 1 9}$} \\
Fertilizer & \multicolumn{7}{c}{ Spraying times of endophytic fungus (B) } \\
\cline { 2 - 9 } (A) & Control & $\mathbf{3}$ times & $\mathbf{6}$ times & Mean & Control & $\mathbf{3}$ times & $\mathbf{6}$ times & Mean \\
\hline Control & 98.1 & 109.8 & 124.2 & 110.7 & 97.7 & 106.5 & 125.9 & 110.0 \\
$\mathbf{3 0 ~ k g ~ N / ~ f e d d a n ~}$ & $123 . .6$ & 133.0 & 143.3 & 133.3 & 125.4 & 137.8 & 141.5 & 134.9 \\
$\mathbf{6 0 ~ k g ~ N / ~ f e d d a n ~}$ & 126.4 & 137.2 & 146.8 & 136.8 & 128.6 & 136.9 & 145.7 & 137.1 \\
Mean & 116.0 & 126.7 & 138.1 & & 117.2 & 127.1 & 137.7 & \\
\hline \multirow{2}{*}{ LSD at 0.05 } & $\mathrm{A}$ & $\mathrm{B}$ & $\mathrm{AB}$ & & $\mathrm{A}$ & $\mathrm{B}$ & $\mathrm{AB}$ & \\
& 2.7 & 2.8 & 4.9 & 2.0 & 2.4 & 4.1 & \\
\hline
\end{tabular}

\subsection{Flowering and fruiting characteristics}

Tabulated results in Tables $(8,9,10$ and 11) show the effects of endophytic fungus and $\mathrm{N}$ fertilizer on the yield of caraway plants during 2018/2019 and 2019/2020 seasons. Results revealed that all spraying times of endophytic fungus significantly increased number of umbels/plant, fruit weight/plant, weight of 1000 fruits and fruit yield/feddan compared with untreated plants (control). However, spraying plants with endophytic fungus 6 times was the most effective treatment in increasing flowering and fruiting characteristics during both seasons. Also, there was a significant difference in yield parameters as a result of nitrogen fertilizer levels in the two seasons. It could be concluded that increasing the $\mathrm{N}$ fertilizer level up to $60 \mathrm{~kg} \mathrm{~N} /$ feddan resulted in the highest flowering and fruiting characteristics for both seasons. Apparently, the interaction between endophytic fungus and nitrogen fertilizer was positively affected caraway yield. The highest values of yield parameters were recorded with plants spraying with endophytic fungus 6 times per season combined with $60 \mathrm{~kg} \mathrm{~N} /$ feddan. These results are in agreement with those mentioned by Eid (2001), Nofal et al., (2001), Aly et al., (2007), Abd El-Azim and Abd El-Gawad (2008), Hemdan (2008), Ibrahim (2014) and Matter and El Sayed (2015). Also, previous studies indicated that application of these endophytic fungi leads to an increase in the growth and productivity of some plants such as basil (Copetta et al., 2006; Toussaint et al., 2008; Baum et al., 2015; Sabra et al., 2018). The obtained results in the present study revealed that caraway 
plant is a very good host for $A$. alternata and hence the fungal spraying might help to improve caraway growth and productivity, especially when planting in conditions like of the experimental conditions with newly reclaimed soils.

Table 8: Umbels number/plant of caraway plants as affected by endophytic fungus (Alternaria alternata) and nitrogen fertilizer during 2018/2019 and 2019/2020 seasons.

\begin{tabular}{|c|c|c|c|c|c|c|c|c|}
\hline \multirow{4}{*}{$\begin{array}{l}\text { Nitrogen } \\
\text { Fertilizer } \\
\text { (A) }\end{array}$} & \multicolumn{7}{|c|}{ Umbels number/ plant } & \\
\hline & \multicolumn{4}{|c|}{ 2018/2019 } & \multicolumn{4}{|c|}{$2019 / 2020$} \\
\hline & \multicolumn{8}{|c|}{ Spraying times of endophytic fungus $(B)$} \\
\hline & Control & $\begin{array}{c}3 \\
\text { times } \\
\end{array}$ & $\begin{array}{c}6 \\
\text { times }\end{array}$ & Mean & Control & 3 times & 6 times & Mean \\
\hline \multirow{4}{*}{$\begin{array}{l}\text { Control } \\
30 \mathrm{~kg} \mathrm{~N} / \text { feddan } \\
60 \mathrm{~kg} \mathrm{~N} / \text { feddan } \\
\text { Mean } \\
\end{array}$} & 42.3 & 45.9 & 55.1 & 47.8 & 44.7 & 48.5 & 56.1 & 49.7 \\
\hline & 53.1 & 56.8 & 65.3 & 58.4 & 53.1 & 55.7 & 66.4 & 58.4 \\
\hline & 64.6 & 72.1 & 75.9 & 70.9 & 64.9 & 75.2 & 77.5 & 72.5 \\
\hline & 53.3 & 58.3 & 65.4 & & 54.2 & 59.8 & 66.7 & \\
\hline \multirow{2}{*}{ LSD at 0.05} & A & B & $\mathrm{AB}$ & & A & $\mathrm{B}$ & $\mathrm{AB}$ & \\
\hline & 1.0 & 1.9 & N.S & & 1.6 & 1.8 & 3.1 & \\
\hline
\end{tabular}

Table 9: Fruit yield (g/plant) of caraway as affected by endophytic fungus ( Alternaria alternata) as spraying and nitrogen fertilizer during 2018/2019 and 2019/2020 seasons.

\begin{tabular}{|c|c|c|c|c|c|c|c|c|}
\hline & & & ruit yie & (g/plar & & & & \\
\hline Nitrogen Fertilizer & & 2018 & & & & 201 & 2020 & \\
\hline & & & Sprayin & times 0 & endophyt & fungus ( & & \\
\hline & Control & $\begin{array}{c}3 \\
\text { times }\end{array}$ & $\begin{array}{c}6 \\
\text { times }\end{array}$ & Mean & Control & 3 times & 6 times & Mean \\
\hline Control & 12.0 & 14.3 & 17.2 & 14.5 & 11.8 & 13.9 & 16.3 & 14.0 \\
\hline $30 \mathrm{~kg}$ N/ feddan & 15.1 & 17.3 & 18.9 & 17.1 & 15.2 & 17.2 & 19.6 & 17.4 \\
\hline $60 \mathrm{~kg} \mathrm{~N} /$ feddan & 18.2 & 22.6 & 27.1 & 22.6 & 18.7 & 22.4 & 27.7 & 22.9 \\
\hline Mean & 15.1 & 18.0 & 21.0 & & 15.3 & 17.8 & 21.2 & \\
\hline ISD at 005 & A & B & $\mathrm{AB}$ & & A & B & $\mathrm{AB}$ & \\
\hline LSD at 0.05 & 0.7 & 0.6 & 1.0 & & 0.8 & 0.7 & 1.2 & \\
\hline
\end{tabular}

Table 10: Weight of 1000-fruits (g) of caraway plants as affected by endophytic fungus (Alternaria alternata) and nitrogen fertilizer during 2018/2019 and 2019/2020 seasons.

\begin{tabular}{|c|c|c|c|c|c|c|c|c|}
\hline \multicolumn{9}{|c|}{ Weight of 1000-fruits (g) } \\
\hline \multirow{3}{*}{$\begin{array}{l}\text { Nitrogen } \\
\text { Fertilizer } \\
\text { (A) }\end{array}$} & \multicolumn{4}{|c|}{$2018 / 2019$} & \multicolumn{4}{|c|}{$2019 / 2020$} \\
\hline & \multicolumn{8}{|c|}{ Spraying times of endophytic fungus (B) } \\
\hline & Control & 3 times & 6 times & Mean & Control & 3 times & 6 times & Mean \\
\hline Control & 5.77 & 7.10 & 8.23 & 7.03 & 5.47 & 6.83 & 8.37 & 6.89 \\
\hline $30 \mathrm{~kg} \mathrm{~N} /$ feddan & 7.00 & 8.57 & 9.40 & 8.32 & 7.30 & 8.50 & 9.30 & 8.37 \\
\hline $60 \mathrm{~kg} \mathrm{~N} /$ feddan & 8.57 & 9.33 & 10.50 & 9.47 & 8.50 & 9.57 & 10.73 & 9.60 \\
\hline Mean & 7.11 & 8.33 & 9.38 & & 7.09 & 8.30 & 9.47 & \\
\hline LSD at 0.05 & A & $\mathrm{B}$ & $\mathrm{AB}$ & & A & B & $\mathrm{AB}$ & \\
\hline & 0.44 & 0.22 & 0.38 & & 0.55 & 0.12 & 0.21 & \\
\hline
\end{tabular}

Table 11: Fruit yield (kg/feddan) of caraway plants as affected by endophytic fungus (Alternaria alternata) and nitrogen fertilizer during 2018/2019 and 2019/2020 seasons.

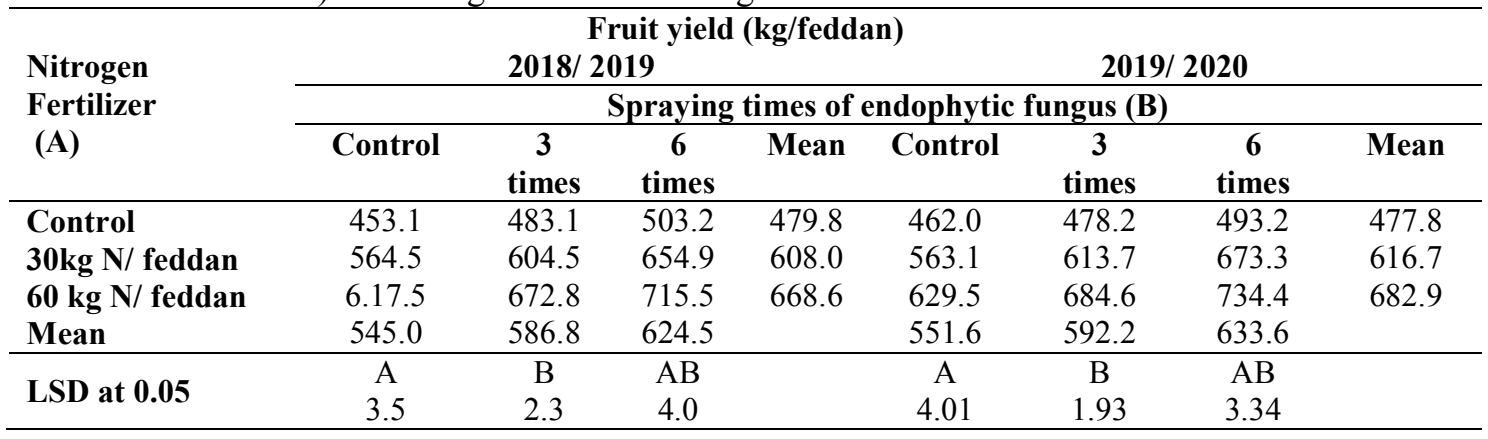




\subsection{Phytochemical composition}

\subsubsection{Essential oil percentage and yield}

The presented data in Tables (12 and 13) indicate the response of essential oil percentage and oil yield/feddan of caraway plants as affected by endophytic fungus and nitrogen fertilizer during $2018 / 2019$ and 2019/2020 seasons. The results revealed that endophytic fungus treatments significantly affected essential oil percentage and oil yield/feddan during the two seasons. Generally, spraying plants 3 or 6 times with endophytic fungus resulted in the highest values compared to the control. On the other hand, the maximum values of essential oil percentage and oil yield were obtained from plants treated with $60 \mathrm{~kg} \mathrm{~N} /$ feddan in both seasons. The interactions between the two studied factors showed significant differences in essential oil percentage and oil yield/feddan for the two seasons. However, the highest essential oil percentage and oil yield/feddan were obtained mostly when plants sprayed 3 times with endophytic fungus combined with $60 \mathrm{~kg} \mathrm{~N} /$ feddan during both seasons. These results are in harmony with those reported by Hemdan (2008), Eid and Kasssem (2009), Shebany and Abdel-Kader (2013), Sabra (2014) and Matter and El Sayed (2015). In this respect, Sabra et al., (2018) revealed that beneficial fungi can be used to increase the quantity and quality of sweet basil. In addition, Kang et al., (2019) pointed out that the host plant exposed to stress absorbs the required amounts of minerals from the soil after endophytic association.

Table 12: Essential oil percentage in caraway fruits as affected by endophytic fungus (Alternaria alternata) and nitrogen fertilizer during 2018/2019 and 2019/2020 seasons.

\begin{tabular}{|c|c|c|c|c|c|c|c|c|}
\hline \multirow{4}{*}{$\begin{array}{l}\text { Nitrogen } \\
\text { Fertilizer } \\
\text { (A) }\end{array}$} & \multicolumn{7}{|c|}{ Essential oil percentage } & \multirow[b]{4}{*}{ Mean } \\
\hline & & 201 & 2019 & & & 2019 & 020 & \\
\hline & \multicolumn{7}{|c|}{ Spraying times of endophytic fungus (B) } & \\
\hline & Control & 3 times & 6 times & Mean & Control & 3 times & 6 times & \\
\hline Control & 2.06 & 2.53 & 2.55 & 2.38 & 2.16 & 2.50 & 2.71 & 2.46 \\
\hline $30 \mathrm{~kg} \mathrm{~N} /$ feddan & 2.61 & 2.75 & 2.89 & 2.75 & 2.53 & 2.82 & 2.89 & 2.75 \\
\hline $60 \mathrm{~kg} \mathrm{~N} /$ feddan & 2.67 & 3.04 & 2.76 & 2.82 & 2.63 & 3.13 & 2.84 & 2.87 \\
\hline Mean & 2.45 & 2.73 & 2.73 & & 2.44 & 2.82 & 2.82 & \\
\hline \multirow{2}{*}{ LSD at 0.05} & $\mathrm{~A}$ & $\mathrm{~B}$ & $\mathrm{AB}$ & & $\mathrm{A}$ & $\mathrm{B}$ & $\mathrm{AB}$ & \\
\hline & 0.07 & .06 & 0.1 & & 0.06 & 0.07 & 0.13 & \\
\hline
\end{tabular}

Table 13: Oil yield (L/feddan) in caraway fruits as affected by endophytic fungus (Alternaria alternata) and nitrogen fertilizer during 2018/2019 and 2019/2020 seasons.

\begin{tabular}{|c|c|c|c|c|c|c|c|c|}
\hline \multirow{4}{*}{$\begin{array}{l}\text { Nitrogen } \\
\text { Fertilizer } \\
\text { (A) }\end{array}$} & \multicolumn{7}{|c|}{ Oil yield (l/feddan) } & \\
\hline & \multicolumn{4}{|c|}{ 2018/2019 } & \multicolumn{4}{|c|}{$2019 / 2020$} \\
\hline & \multicolumn{8}{|c|}{ Spraying times of endophytic fungus (B) } \\
\hline & Control & $\begin{array}{c}3 \\
\text { times }\end{array}$ & $\begin{array}{c}6 \\
\text { times }\end{array}$ & Mean & Control & $\begin{array}{c}3 \\
\text { times }\end{array}$ & $\begin{array}{c}6 \\
\text { times }\end{array}$ & Mean \\
\hline Control & 9.35 & 12.21 & 12.85 & 11.47 & 9.98 & 11.94 & 13.37 & 11.76 \\
\hline $30 \mathrm{~kg} \mathrm{~N} /$ feddan & 14.75 & 16.64 & 18.91 & 16.77 & 14.23 & 17.31 & 19.48 & 17.00 \\
\hline $60 \mathrm{~kg} \mathrm{~N} /$ feddan & 16.49 & 20.45 & 19.75 & 18.90 & 16.54 & 21.45 & 20.88 & 19.62 \\
\hline Mean & 13.53 & 16.53 & 17.17 & & 13.58 & 16.90 & 17.91 & \\
\hline \multirow{2}{*}{ LSD at 0.05} & A & $\mathrm{B}$ & $\mathrm{AB}$ & & A & B & $\mathrm{AB}$ & \\
\hline & 0.47 & 0.33 & 0.58 & & 0.42 & 0.52 & 0.73 & \\
\hline
\end{tabular}

\subsubsection{Leaf mineral content}

As shown in Tables 14, 15 and 16, contents of N, P and K in caraway leaves were significantly varied according to endophytic fungus spraying and nitrogen levels. Generally, plants sprayed with endophytic fungus 6 times and treated with $60 \mathrm{~kg} \mathrm{~N} /$ feddan resulted in the highest $\mathrm{N}$ content compared to the other combined treatments in both seasons. Meanwhile, combined treatment of endophytic fungus 6 times per season and $30 \mathrm{~kg} \mathrm{~N} /$ feddan resulted in the highest values of $\mathrm{P}$ and $\mathrm{K}$ contents compared to the other combined treatments in most cases. The current findings are similar to those reported by Abdou et al., (2004), Shebany and Abdel-Kader (2013), Sabra (2014) and Matter and El Sayed (2015). In this respect, Strobel et al., (2004) on tall fescue and Ren et al., (2008) on ryegrass and studied the impact of $\mathrm{N}$ fertilizer and endophytic fungi on the mineral content in the and revealed that endophytic fungi increased the mineral concentrations in roots and shoots. 
Table 14: Nitrogen percentage in caraway leaves as affected by endophytic fungus (Alternaria alternata) and nitrogen fertilizer during 2018/2019 and 2019/2020 seasons.

\begin{tabular}{|c|c|c|c|c|c|c|c|c|}
\hline \multicolumn{9}{|c|}{ Nitrogen $\%$} \\
\hline \multirow{3}{*}{$\begin{array}{l}\text { Nitrogen Fertilizer } \\
\text { (A) }\end{array}$} & & 2018/ & 2019 & & & 2019 & 2020 & \\
\hline & \multicolumn{8}{|c|}{ Spraying times of endophytic fungus (B) } \\
\hline & Control & 3 times & 6 times & Mean & Control & 3 times & 6 times & Mean \\
\hline Control & 1.37 & 1.58 & 1.64 & 1.53 & 1.32 & 1.47 & 1.71 & 1.50 \\
\hline $30 \mathrm{~kg}$ N/ feddan & 1.55 & 1.75 & 1.78 & 1.69 & 1.54 & 1.64 & 1.73 & 1.64 \\
\hline $60 \mathrm{~kg} \mathrm{~N} /$ feddan & 1.74 & 1.78 & 1.85 & 1.79 & 1.71 & 1.81 & 1.88 & 1.80 \\
\hline Mean & 1.55 & 1.70 & 1.76 & & 1.52 & 1.64 & 1.77 & \\
\hline LSD at 0.05 & A 0.06 & B 0.04 & $\begin{array}{l}\mathrm{AB} \\
0.07\end{array}$ & & A 0.04 & B 0.03 & $\mathrm{AB} 0.05$ & \\
\hline
\end{tabular}

Table 15: Phosphorus percentage in caraway leaves as affected by endophytic fungus (Alternaria alternata) and nitrogen fertilizer during 2018/2019 and 2019/2020 seasons.

\begin{tabular}{|c|c|c|c|c|c|c|c|c|}
\hline \multicolumn{9}{|c|}{ Phosphorus \% } \\
\hline \multirow{3}{*}{$\begin{array}{l}\text { ( A ) Nitrogen } \\
\text { Fertilizer }\end{array}$} & \multicolumn{4}{|c|}{$2018 / 2019$} & \multicolumn{4}{|c|}{ 2019/2020 } \\
\hline & \multicolumn{8}{|c|}{ Spraying times of endophytic fungus (B) } \\
\hline & Control & 3 times & 6 times & Mean & Control & 3 times & 6 times & Mean \\
\hline Control & 0.30 & 0.34 & 0.40 & 0.35 & 0.28 & 0.36 & 0.43 & 0.36 \\
\hline $\begin{array}{l}30 \mathrm{~kg} \mathrm{~N} / \\
\text { feddan }\end{array}$ & 0.36 & 0.48 & 0.53 & 0.46 & 0.41 & 0.45 & 0.53 & 0.46 \\
\hline $\begin{array}{l}60 \mathrm{~kg} \mathrm{~N} / \\
\text { feddan }\end{array}$ & 0.34 & 0.36 & 0.40 & 0.37 & 0.35 & 0.38 & 0.40 & 0.38 \\
\hline Mean & 0.33 & 0.39 & 0.44 & & 0.35 & 0.40 & 0.45 & \\
\hline LSD at 0.05 & $\begin{array}{c}\mathrm{A} \\
0.03\end{array}$ & $\begin{array}{c}\mathrm{B} \\
0.02\end{array}$ & $\begin{array}{c}\mathrm{AB} \\
0.04\end{array}$ & & $\begin{array}{c}\mathrm{A} \\
0.03\end{array}$ & $\begin{array}{c}\mathrm{B} \\
0.02\end{array}$ & $\begin{array}{c}\mathrm{AB} \\
0.04\end{array}$ & \\
\hline
\end{tabular}

Table 16: Potassium percentage in caraway leaves as affected by endophytic fungus (Alternaria alternata) and nitrogen fertilizer during 2018/2019 and 2019/2020 seasons.

\begin{tabular}{|c|c|c|c|c|c|c|c|c|}
\hline \multicolumn{9}{|c|}{ Potassium \% } \\
\hline \multirow{3}{*}{$\begin{array}{l}\text { Nitrogen } \\
\text { Fertilizer } \\
\text { (A) }\end{array}$} & \multicolumn{4}{|c|}{$2018 / 2019$} & \multicolumn{4}{|c|}{$2019 / 2020$} \\
\hline & \multicolumn{8}{|c|}{ Spraying times of endophytic fungus $(B)$} \\
\hline & Control & 3 times & 6 times & Mean & Control & 3 times & 6 times & Mean \\
\hline Control & 1.27 & 1.37 & 1.45 & 1.37 & 1.37 & 1.39 & 1.50 & 1.42 \\
\hline $30 \mathrm{~kg} \mathrm{~N} /$ feddan & 1.49 & 1.57 & 1.63 & 1.56 & 1.45 & 1.57 & 1.71 & 1.58 \\
\hline $60 \mathrm{~kg} \mathrm{~N} /$ feddan & 1.50 & 1.65 & 1.60 & 1.58 & 1.51 & 1.67 & 1.64 & 1.61 \\
\hline Mean & 1.42 & 1.53 & 1.56 & & 1.44 & 1.54 & 1.61 & \\
\hline \multirow{2}{*}{ LSD at 0.05} & A & $\mathrm{B}$ & $\mathrm{AB}$ & & A & $\mathrm{B}$ & $\mathrm{AB}$ & \\
\hline & 0.03 & 0.03 & 0.06 & & 0.07 & 0.03 & 0.06 & \\
\hline
\end{tabular}

\subsection{Total carbohydrates percentage}

The obtained results in Table (17) revealed that all treatments of endophytic fungus and nitrogen fertilizer caused significant differences in total carbohydrates percentage in caraway leaves during both seasons. However, the highest total carbohydrates percentages resulted from the individual treatment of either endophytic fungus 6 times per season or $60 \mathrm{~kg} \mathrm{~N} /$ feddan in both seasons. The interaction between endophytic fungus and $\mathrm{N}$ fertilizer caused significant differences in total carbohydrates percentage. The highest values were obtained from the combined treatment of spraying endophytic fungus 3 times and $60 \mathrm{~kg} \mathrm{~N} /$ feddan for both seasons. These results are in parallel to those obtained by Hemdan (2008), Eid and Kasssem (2009), Sabra (2014) and Matter and El Sayed (2015). In this regard, several investigators reported that some endophytic fungi are among the biologically active species. They added that it involves in the production of chemically diverse metabolites compounds. Besides, endophytic fungi have been reported to increase carbohydrate concentrations in host plant (Hunt et al., 2005; Rasmussen et al., 2007; Ebeid and Shebany, 2017). 
Table 17: Total carbohydrates percentage in caraway leaves as affected by endophytic fungus (Alternaria alternata) and nitrogen fertilizer during 2018/2019 and 2019/2020 seasons.

\begin{tabular}{lcccccccc}
\hline \multicolumn{7}{c}{ Total carbohydrates percentage } \\
\hline Nitrogen & \multicolumn{7}{c}{ Sp18/ 2019 } & \multicolumn{7}{c}{$\mathbf{2 0 1 9 / 2 0 2 0}$} \\
Fertilizer & \multicolumn{7}{c}{ Spraying times of endophytic fungus (B) } \\
\cline { 2 - 9 } (A) & Control & $\mathbf{3}$ times & $\mathbf{6}$ times & Mean & Control & $\mathbf{3}$ times & $\mathbf{6}$ times & Mean \\
\hline Control & 10.70 & 12.95 & 14.93 & 12.86 & 11.88 & 13.74 & 15.49 & 13.70 \\
$\mathbf{3 0 ~ k g ~ N / ~ f e d d a n ~}$ & 13.88 & 16.03 & 18.00 & 15.97 & 14.74 & 16.47 & 17.73 & 16.31 \\
$\mathbf{6 0 ~ k g ~ N / ~ f e d d a n ~}$ & 15.96 & 18.63 & 17.52 & 17.37 & 15.49 & 18.35 & 17.31 & 17.04 \\
Mean & 13.51 & 15.87 & 16.81 & & 14.03 & 16.19 & 16.84 & \\
LSD at 0.05 & $\mathrm{A}$ & $\mathrm{B}$ & $\mathrm{AB}$ & $\mathrm{A}$ & $\mathrm{B}$ & $\mathrm{AB}$ & \\
& 0.64 & 0.26 & 0.45 & 0.26 & 0.34 & 0.59 & \\
\hline
\end{tabular}

\subsection{Essential oil constituents}

The presented data in Table (18) show the different chemical compounds in essential oil of caraway fruits in response to endophytic fungi and $\mathrm{N}$ fertilizer treatments. The results indicated that the most important chemical compounds in essential oil are carvone, limonene, linalool, caryophyllene, $\beta$ pinene, p-cymene, $\alpha$-pinene, carveol and dihydrocarvone. The mean values of carvone (major compound) in the essential oil showed gradually increase due to increasing nitrogen level from 0 to 30 then $60 \mathrm{~kg} \mathrm{~N} / \mathrm{fed}$. The same trend was noticed with spraying times of Alternaria alternata fungus. Most of the different treatments for nitrogen fertilizer and spraying times of Alternaria alternata fungus showed an increase in some of these component especially, carvone, linalool, $\alpha$-Pinene and carvone to limonene $(\mathrm{C} / \mathrm{L})$ ratio compared with the control (untreated plants) which, increased limonene content. The highest level of caryophyllene compound $(2.90 \%)$ recorded when plants sprayed 6 times endophytic fungi without nitrogen fertilizer, followed by linalool, which recorded the maximum value in essential oil (2.22\%) when sprayed 3 times combined with $60 \mathrm{~kg} \mathrm{~N} /$ feddan. The maximum carvone content $(73.8 \%)$, the minimum limonene level $(13 \%)$ and the highest ratio $(4.93 \%)$ of carvone to limonene $(\mathrm{C} / \mathrm{L})$ were resulted from spraying caraway plants 3 times per season of endophytic fungus and using $60 \mathrm{~kg} \mathrm{~N} /$ feddan compared to the control and other treatments. These results are in accordance with the findings of Hendawy and Khalid (2011), Sabra (2014), Matter and El Sayed (2015) and Omar (2020) on caraway. Interestingly, there is evidence that biosynthesis of carvone and limonene occurs via the same pathway. This implies that limonene in both intermediate in the biosynthesis of carvone, as well as the end product (Bouwmester et al., 1995).

Table 18: Chemical composition of the essential oil in caraway fruits as affected by endophytic fungus (Alternaria alternata) and nitrogen fertilizer during 2018/2019 and 2019/2020 seasons.

\begin{tabular}{|c|c|c|c|c|c|c|c|c|c|}
\hline \multirow{4}{*}{ Compound \% } & \multicolumn{9}{|c|}{ Nitrogen fertilizer (kg N/feddan) } \\
\hline & \multicolumn{3}{|c|}{ Control } & \multicolumn{3}{|c|}{30} & \multicolumn{3}{|c|}{60} \\
\hline & \multicolumn{9}{|c|}{ Spraying times of endophytic fungus } \\
\hline & Cont. & $\begin{array}{c}3 \\
\text { times }\end{array}$ & $\begin{array}{c}6 \\
\text { times }\end{array}$ & Cont. & $\begin{array}{c}3 \\
\text { times }\end{array}$ & $\begin{array}{c}0 \\
\text { times }\end{array}$ & Cont. & $\begin{array}{c}3 \\
\text { times }\end{array}$ & $\begin{array}{c}6 \\
\text { times }\end{array}$ \\
\hline$\alpha$-pinene & 0.37 & 0.55 & 0.70 & 0.45 & 0.80 & 0.92 & 1.00 & 1.2 & 1.08 \\
\hline$\beta$-pinene & 1.08 & 0.71 & 0.81 & 0.71 & 0.88 & 1.05 & 0.9 & 1.08 & 0.83 \\
\hline Limonene & 25.4 & 22.60 & 20.60 & 21.00 & 19.80 & 17.5 & 19.00 & 17.00 & 17.2 \\
\hline P-cymene & 0.55 & 0.65 & 0.89 & 0.68 & 1.00 & 1.10 & 0.78 & 0.97 & 0.80 \\
\hline Linalool & 1.82 & 1.83 & 2.00 & 1.81 & 1.98 & 2.10 & 1.92 & 2.22 & 2.08 \\
\hline Caryophyllene & 1.82 & 2.05 & 2.90 & 1.70 & 1.17 & 1.19 & 1.00 & 0.92 & 0.78 \\
\hline Carvone & 65.22 & 67.22 & 69.5 & 68.11 & 71.3 & 73.2 & 71.43 & 73.8 & 73.7 \\
\hline Dihydrocarvone & 0.17 & 0.24 & 0.26 & 0.23 & 0.38 & 0.35 & 0.27 & 0.42 & 0.38 \\
\hline Carveol & 0.33 & 0.40 & 0.45 & 0.38 & 0.63 & 0.88 & 0.40 & 0.82 & 0.80 \\
\hline Total & 96.66 & 96.25 & 98.11 & 95.07 & 97.94 & 98.29 & 96.7 & 98.43 & 97.65 \\
\hline $\begin{array}{l}\text { Unidentified } \\
\text { compound }\end{array}$ & 3.34 & 3.75 & 1.89 & 4.93 & 2.06 & 1.71 & 3.30 & 1.57 & 2.35 \\
\hline $\begin{array}{l}\text { Carvone/Limonene } \\
\text { ratio }\end{array}$ & 2.6 & 2.97 & 3.37 & 3.24 & 3.60 & 4.18 & 3.76 & 4.93 & 4.28 \\
\hline
\end{tabular}


Results of our study may be due to the role of nitrogen fertilization in increase the growth and development of the caraway plants; where the use of endophytic fungi as A. alternata was found to release certain of phytohormones and auxins which could enhance plant growth and yield of caraway through improvement uptake of nutrients and enhancing photosynthesis process in plants (AbouAlhamed and Shebany, 2012). In this respect, Hawaka (2000) revealed that microorganisms as bio-fertilizers may affect the growth and production of plants through their actions as nitrogen fixation, promoting substances, organic acids and enhancing nutrients uptake as well as through protection of pathogens.

\section{Conclusion}

It could be concluded that spraying caraway plant with Alternaria alternata at $0.3 \%$ as one of endophytic fungus 3 or 6 times per season combined with $60 \mathrm{~kg} \mathrm{~N} /$ feddan as ammonium sulfate under the newly reclaimed sandy soil conditions gave the best vegetative growth and productivity as well as improved the chemical compounds in essential oil of caraway fruits and markedly increased quality of oil (oil \%, carvone content and carvone to limonene ratio) compared to the control.

\section{References}

Abd EL-Azim, M.W.A. and A.M.A. Abd El-Gawad, 2008. Effect of treatment with tryptophan and yeast onsoil microbial activities, growth and productivity of Thymus vulgaris L. under middle Sinai conditions.Annals of Agric. Sci. (Cairo), 53(1): 105-116.

Abdel-Rahman, S.S.A., M.A. Faragallah, and A.A.S. Abdel-Kader, 2008. Growth, yield and chemical composition of Foeniculum vulgare, Mill. Plant as affected by nitrogen, dry yeast and tryptophan application. Assiut J. Agric. Sci., 39(3): 115-134.

Abdou, M.A., A.A. El-Sayed, F.S. Badran, and R.M. Salah El-Deen, 2004. Effect of planting density andchemical and biofertilization on vegetative growth, yield and chemical composition of fennel (Foeniculum vulgare, Miller): II- Effect of NPK chemical fertilization and biofertilization treatments.Annals of Agricultural Science, Moshtohor, 42(4): 1923-1937.

AbouAlhamed, M.F. and Y.M. Shebany, 2012. Endophytic Chaetomium globosum enhances maize seedling copper stress tolerance. Plant Biology, 14(5): 859-863.

Ahmed, E.F.A., 2017. Evaluation of certain fertilizing programs on anise and black cumin plants. Ph.D. Thesis. Fac. Assiut Univ., Egypt.

Aly, M.K., M.A. Mohamed, F.A. Attia, A.A. El-Sayed, and M.H. Abd El- Gawad, 2007. Effect of some organic and biofertilization treatments on coriander plants. II- Volatile oil and chemical composition. 1st Inter.Conf Desert. Cultivation, Problem \& Solutions. Minia Univ., 113-125.

Analytical software, 2005. Statistix 8.1 for windows analytical software. Tallahassee, Florida.

Ashraf, M. and A. Orooj, 2006. Salt stress effects on growth, ion accumulation and seed oil concentration in an arid zone traditional medicinal plant ajwain (Trachyspermum ammi L.). Journal of Arid Environments, 64: 209-220.

Aüimoviü, M.G., Z.K. Dolijanoviü, S.I. Oljapa, D.C. Kovapeviü, and M.V. Oljapa, 2015.'Effect of Organic and Mineral Fertilizers on Essential Oil Content in Caraway, Anise and Coriander Fruits'. Acta Sci. Pol., Hortorum Cultus, (1): 95-103.

Baranauskiene, R., P.R. Venskutonis, P. Viskelis, and E. Dambrauskiene, 2003. 'Influence of nitrogen fertilizers on the yield and composition of thyme (Thymus vulgaris)'. J. of Agric. and Food Chem., 51 (26): 7751-7758

Baum, C., W. El-Tohamy, and N. Gruda, 2015. Increasing the productivity and product quality of vegetable crops using arbuscular mycorrhizal fungi: A review. Sci., Hortic., 187: 131-141.

Black, C.A., D.D. Evans, J.I. Nhite, L.E. Ensminger, and F.E. Clark, 1982. Methods of Soil Analysis. J. Amer. Soc. Agron. Inc. Madison, Wisconsin U.S.A.

Bouwmeester, H.J., J.A.R. Davines, H.G. Smid and R.S.A . Welten, 1995. Physiological limitation to corvone yield in caraway (Carum carvi L. ). Industrial crops and products, 4: 39-51. 
Bricker, B., 1991. MSTATC: 'A micro computer program from the design management and analysis of agronomic research experiments', Michigan State University 1991.

Copetta, A., G. Lingua, and G. Berta, 2006. Effects of three AM fungi on growth, distribution of glandular hairs, and essential oil production in Ocimum basilicum L. var. Genovese. Mycorrhiza, 16: 485-494.

Cottenie, A., M. Verloo, M. Velghe, and R. Camerlynck, 1982. 'Chemical Analysis of Plant and Soil'. Manual Laboratory of Analytical and Agrochemistry. Ghent State Univ. Press, Belgium.

Dyduch, J., A. Najda, and N. Brzozowski, 2006. 'Growth and chemical content of caraway (Carum carviL.) inthe first year of cultivation'. Folia Hortic., 1: 108-112.

Ebeid, A.F.A. and Y.M. Shebany, 2017. Influence of Endophytic Fungi and Growing Media on the Growth and Some Chemical Constitutes in Chrysophyllum oliviforme Seedlings. Res. J. of Pharma., Biolog. \& Chem. Sci. 8(3): 533.

Eid, M.I. and A.H.M. Kassem, 2009. Effect of phosphorein and active dry yeast on Calendula officinalis,L. J. Product and Dev., 14(2): 491-505.

Eid, M.I., 2001. Response of coriander plant to foliar spray with active yeast and phosphorus fertilization. J.Agric. Sci. Mansoura, 26(12): 7869-7878.

El-Din, A.A.E., S.F. Hendaway, E.E. Aziz, and E.A. Omer, 2010. 'Enhancing growth, yield and essential oil of caraway plants by nitrogen and potassium fertilizers'. Int. J. Acad. Res., 2(3) : 192-197.

El-Tohamy, W.A. and N.H.M. El-Greadly, 2007. Physiological response, growth, yield and quality of snapbeans in response to foliar application of yeast, vitamin E and zinc under sandy condition. Aust. J. orBasic and Appl. Sci., 1(3): 294-299.

Filip, P., R.W.S. Weber, O. Sterner, and T. Anke, 2003. 'Hormonemate, a new cytotoxic and apoptosisinducing compound from the endophytic fungus Hormone madematioides. 1. Identification of the producing strain, isolation and biological properties of hormonemate. Z'Naturforsch, 58: 547552.

Gomez, K.A. and A.A. Gomez, 1983. Statistical Procedure for Agricultural Research. A Wiley InterScience Publication. John Wiley \&Sone Inc. New York.

Guenther, E., 1961. "The Essential Oils". Van Nostrand comp. Inc. New York, Vol. III, pp. 448.

Hawaka, F.I.A., 2000. Effect of using single and composite inoculation with Azospirillum brasilense, Bacillus megatherium var. phosphaticum and Glomusma crocarpus for improving growth of Zea mays. J. Agric. Sci. Mansoura, Egypt, 32(12): 239-252.

Hemdan, S.H., 2008. Effect of some organic and biofertilization treatments on anise plants. M. Sc. Thesis, Fac.of Agric., Minia University.

Hendawy, S.F. and K.A. Khalid, 2011. Effect of chemical and organic fertilizers on yield and essential oil of chamomile flower heads. Medicinal and Aromatic Plant Science and Biotechnology, 5(1): 43-48.

Herbert, D., P. Phipps, and R. Strange, 1971. Determination of total carbohydrates. Methods in Microbiology, 5(8):290-344.

Hunt, M.G.; S. Rasmussen, P.C.D. Newton, A.J. Parsons, and J.A. Newman, 2005. Near-term impacts of elevated $\mathrm{CO} 2$, nitrogen and fungal endophyte-infection on Lolium perenne L. growth, chemical composition and alkaloid production. Plant Cell Environment, 28: 1345-1354.

Ibrahim, T.I.E.I., 2014. Influence of some agricultural treatments on Ammi visnaga plants. Ph.D. Thesis, Fac. of Agric. Minia Univ., Egypt.

Jackson, M.L., 1973. Soil Chemical Analysis. Prentice-Hall, Inc. Englewood Cliffs, N.J. New Delhi, India, 498.

Kandil, M.A.M., M.E. Khatab, S.S. Ahmed, and E. Schnug, 2009. 'Herbal and essential oil yield of Genovese basil (Ocimum basilicum L.) grown with mineral and organic fertilizer sources in Egypt'. J. Kulturpfl. 61(12): 443-449.

Kang, S.M., M. Hamayun, M.A. Khan, A. Iqbal, and I.J. Lee, 2019. Bacillus subtilis JW1 enhances plant growth and nutrient uptake of Chinese cabbage through gibberellins secretion. J Appl Bot Food Qual., 92:172-8. 
Kenawy, A.G., 2010. Effect of some biofertilization treatments on the growth, yield and chemical compositionof Hibiscus sabdariffa, L. plants. M.Sc. Thesis, Fac. of Agric., Mania Univ., Eygpt.

Khan, M.S., A. Zaidi, P.A. Wani, and M. Oves, 2009. 'Role of plant growth promoting rhizobacteria in the remediation of metal contaminated soils'. Environmental Chemistry Letters, 7(1): 1-19.

Kocourkova, B., J. Sedlakova, and V. Holubova, 1999. Morfologicke a kvalitativ niznakyregi strovany chodrud. In : Proc. Conf. Caraway in present plant production. MZLU Brno: 34-41.

Kozera, W., E. Majcherczak, and B. Barczak, 2013. 'Effect of varied NPK fertilisation on the yield size, content of essential oil and mineral composition of caraway fruit (Carum carvi L.)'. J. Elem., 2: 255-267.

Malinowski, D.P., G.A. Alloush, and D.P. Belesky, 2000. Leaf endophyte Neotyphodium coenophialum modifies mineral uptake in tall fescue. Plant Soil, 227: 115-126.

Matter, F.M.A. and S.A.A. El Sayed, 2015. Influence of Mixed NPK Fertilizers with Foliar Spray of Active Dry Yeast on Caraway under Newly Reclaimed Soil Conditions. Middle East J. Appl. Sci.., 5(2): 423-430.

Montesinos, E., 2003. 'Plant-associated microorganisms: a view from the scope of microbiology'. International Microbiology, 6(4): 221 - 223.

Nofal, E.S., Y.R. Kandel, F.A. Menesi, K.A. Reda, M. Taher, and Z.T. Zaki, 2001. Effect of some cultural practices on growth and chemical composition of some medicinal plants in Northern Sinai (Ammi visnaga, L.) proc. The Fifth Arabian Hort. Conf., Ismailia, Egypt, 24-28: 51-60.

Omar, A.A., 2020. Response of caraway plant to zinc and humic acid treatment. M.Sc. Thesis, Fac . Agric . Assiut Univ, Egypt .

Omer, E.A., A.G.A. Elsayed, A. El-Lathy, M.E. Khattab, and A.S. Sabra, 2008. 'Effect of the nitrogen fertilizer forms and time of their application on the yield of herb and essential oil from Ocimum americanum L. 'Herba Pol., 54(1): 34-46.

Paschalina, S.C., T.V. Koutsos, and S.T. Katsiotis, 2006. 'Study on nitrogen fertilization rate on fennel cultivars for essential oil yield and composition'. J. of Vegetable Sci., 12 (2): 85-93.

Peter, K., 2006. Handbook of herbs and spices (Woodhead Publishing, Cambridge, 2006).

Rasmussen, S., A.J. Parsons, S. Bassett, M.J. Christensen, D.E. Hume, and L.J. Johnson, 2007. High nitrogen supply and carbohydrate content reduce fungal endophyte and alkaloid concentration in Lolium perenne. New Phytologist, 173: 787-797.

Ren, A.Z., Y.B. Gao, W. Wang, J.L. Wang, and N.X. Zhao, 2008. Influence of nitrogen fertilizer and endophyte infection on ecophysiological parameters and mineral element content of perennial ryegrass. Journal of Integrative Plant Biology. doi: 10.1111/j.1744-7909.2008.00721.

Sabra, M., A. Aboulnasr, P. Franken,E. Perreca, L.P. Wright, and I. Camehl, 2018. Beneficial Root Endophytic Fungi Increase Growth and Quality Parameters of Sweet Basil in Heavy Metal Contaminated Soil. Front. Plant Sci. 9:1726.

Sabra, M.M., 2014. Physiological studies on khella (Amm ivisnaga) plant. M.Sc. Thesis, Fac. Agric., Fayoum University.

Sembratowicz, I. and A. Czech, 2005. 'Natural antioxidants in the food'. Post. NaukRoln. 1: 75-88.

Shalan, M., T. Abdel-Latif, and E. Ghadban, 2006. Effect of water salinity and some nutritional compounds on the growth and production of sweet marjoram plants (Majorana hortensis L.). Egypt J. Agric. Res, 84: 959-968.

Shebany, Y.M. and A.A.S Abdel-Kader, 2013. Influence of endophytic fungi on growth and essential oil yield and its composition in Ocimum basilicum, L. plant. Egypt. J. of appl., Sci., 28(1): 22-39.

Smith, N.R. and V.T. Dawson, 1944. 'The Bacteriostatic Action of Rose Bengal in Media Used for the Plate Counts of Soil Fungi'. Soil Science, 58: 467-471.

Strobel, G.A., B. Daisy, U. Castillo, and J. Harper, 2004. Natural products from endophytic microorganisms. Journal of Natural Products. 67(2): 257-268.

Swarupa, U., K.T. Sadawarte, and S.G. Wankhade, 2003. 'Growth and yield of isabgol (Plantago ovata forsk.) as influenced by nitrogen and phosphorus levels'. Agric. Sci. Digest., 23 (1): 24-27. 
Taie, H.A.A., Z.A.E.R. Salama, and S. Radwan, 2010. 'Potential activity of basil plants as a source of antioxidants and anticancer agents as affected by organic and bio-organic fertilization'. Not. Bot. Hort. Agrobot. Cluj. 38(1): 119-127.

Toussaint, J.P., M. Kraml, M. Nell, S.E. Smith, F.A. Smith, and S. Steinkellner, 2008. Effect of Glomus mosseae on concentrations of rosmarinic and caffeic acids and essential oil compounds in basil inoculated with Fusarium oxysporumf.sp. basilici. Plant Pathol., 57: 1109-1116.

Uroz S., C. Calvaruso, M.P. Turpault, and P. Frey-Klett, 2009. 'Mineral weathering by bacteria: ecology, actors and mechanisms'. Trends in Microbiology, 17(8):378-87.

Wenzel, W.W., 2009. 'Rhizosphere processes and management in plant-assisted bioremediation (phytoremediation) of soils'. Plant and Soil, 321(1-2): 385-408. 